\title{
AUTHENTICATION OF SPRAGUE DAWLEY RATS (RATTUS NORVEGICUS) FAT WITH GC-MS (GAS CHROMATOGRAPHY-MASS SPECTROMETRY) COMBINED WITH CHEMOMETRICS
}

\section{ANY GUNTARTI ${ }^{1,2 *}$, KARINA PRIMATYAS NINGRUM ${ }^{1}$, IBNU GHOLIB GANDJAR ${ }^{1}$, NINA SALAMAH ${ }^{1,2}$}

${ }^{1}$ Faculty of Pharmacy, Universitas Ahmad Dahlan, Yogyakarta 55164, Indonesia, ${ }^{2}$ Ahmad Dahlan Halal Center, Universitas Ahmad Dahlan, Yogyakarta, Indonesia

*Email: any_guntarti@yahoo.co.id

Received: 31 Oct 2020, Revised and Accepted: 23 Dec 2020

\section{ABSTRACT}

Objective: Misuse of rat meat as food worried people. Rat meat can come from research waste; one of the rats used in the research was the Sprague Dawley. Analysis of rat meat in food can be done using fat. The aim of this study was to authenticate rat fat with GC-MS combined with chemometrics.

Methods: The meat of Sprague Dawley rats, wild boar, goats, cow, and processed meatballs was put in the oven at $90-100{ }^{\circ} \mathrm{C}$ for \pm one hour, then derivatized with $\mathrm{BF}_{3}$ and $\mathrm{NaOH}$ in methanol to get the methyl ester for injected in GC-MS instrument. The results obtained were in the form of chromatograms and spectrograms. The data was processed using Principal Component Analysis (PCA) to grouping rat's meat with others (wild boars, goats, cows, and processed meatballs).

Results: Rat meat fatty acid analysis results with GC-MS were obtained oleate $(43.32 \pm 1.43) \%$, linolenate $(32.24 \pm 1.46) \%$, palmitate $(19.75 \pm 0.09) \%$, palmitoleate $(1.14 \pm 0.06) \%$, stearate $(0.26 \pm 0.01) \%$, myristate $(0.18 \pm 0.01) \%$, margarate $(0.15 \pm 0.02) \%$, and pentadecanoate $(0.14 \pm 0.01) \%$. The PCA chemometrics results showed that rat meats had scores that close to cows, which meant they had similar fatty acid composition.

Conclusion: The GC-MS method, combined with PCA chemometrics, tested rat fat with other animals and processed meatballs samples on the market.

Keyword: Chemometrics, Fatty acids, GC-MS, PCA, Rat, Sprague dawley

(C) 2021 The Authors. Published by Innovare Academic Sciences Pvt Ltd. This is an open access article under the CC BY license (https://creativecommons.org/licenses/by/4.0/) DOI: https://dx.doi.org/10.22159/ijap.2021v13i2.40130. Journal homepage: https://innovareacademics.in/journals/index.php/ijap

\section{INTRODUCTION}

Food is one of the basic human needs. Lately, the safety of foods circulating in society is no longer guaranteed [1]. The production of meat-based food has a high susceptibility to counterfeiting, especially a mix of meat from wild animals [2]. Rat meat is classified as non-halal [3]. This has become attention to Indonesia; since the majority of the people are Muslim.

Based on the Foundation for Biomedical Research (FBR), 95\% of all animals in the laboratory are rats [4]. White rats are often used as experimental animals because their genetic characteristics are unique. Also, they are easy to breed, cheap, and easy to be obtained. One of the rats' furrows used was the Sprague Dawley rat. They are often used for research on metabolism, diabetes, and nutrition. The 'abundant waste' from the research results can be misused as a substitute ingredient for other animals' meat; since they have similar characteristics. Food authentication analysis is an important issue to ensure that food quality is in accordance with its labeling [5]. Analytical methods to identify 'authenticity' can be based on detecting fat, protein, or DNA biomarker [6, 7]. Fat detection is a widely used method. The following are the examples of ways which have been successfully investigated by using Polymerase Chain Reaction (PCR) [8]: High Perform Liquid Chromatography (HPLC) [9], Gas Chromatography (GC) [10], Form Transform Infra-Red (FTIR) [11, 12], electronic nose [13], Liquid Chromatography-Mass Spectroscopy (LC-MC) [14], and Nuclear Magnetic Resonance (NMR) Spectroscopy [15].

Fatwas chosen since it is a form of a sample that is easy to be obtained-only have to extract non-polar solvents [16]. Fat in animals is commonly found in adipose tissue [17]. The distribution of fat in meat can serve as a differentiator of meat from its animal (source). The composition of fat in meat is influenced by animal species, sex and types of food [18]. The grouping of fatty acid based on the types of animal can be done using PCA chemometrics analysis $[12,19]$. Analysis using PCA shows that fat from cows, dogs, goats, pigs and chickens can be identified and distinguished [20].
The researches which have been done about "rats' fat in food preparations" were analyzed using FTIR combined with chemometrics [21]. However, this method has the disadvantage of not being able to identify the types and content of each fat component from a sample with certainty [22]. Therefore, GC-MS was used for the analysis; since it is able to find out the types of fatty acid from the sample components-combined with chemometrics PCA, which is able to classify fats from animal species.

\section{MATERIALS AND METHODS}

\section{Tools and ingredients}

Tools: Gas Chromatography-Mass Spectrometry instrument (GCMS Shimadzu Japan, type GCMS-QP2010 SE) with an auto-sampler machine, analytical scale, electric stove, oven, vortex, glassware.

\section{Ingredients}

The fat of Sprague Dawley rat was taken from Animal Test Rats (UD. Wistar), Yogyakarta, fat for wild boar from the forest in Central Java, fat for Goat from a goat satay seller in Yogyakarta, and fat for cows from an animal center in Yogyakarta. n-hexane, $0.2 \mathrm{~N} \mathrm{NaOCH}_{3}$ solution (obtained from mixing solid $\mathrm{NaOH}$ in methanol), $\mathrm{BF}_{3}$ solution, saturated $\mathrm{NaCl}$, and anhydrous $\mathrm{Na}_{2} \mathrm{SO}_{4}$ [23].

\section{Process of the research}

\section{Sample preparation}

The fat of Sprague Dawley rats and other animals (boar, goat, and cow) were taken, washed, cut into small pieces, and stored in a freezer to keep the meat stable.

\section{Fat extraction}

Oil extraction is carried out by an extraction procedure using an oven at a temperature of $90-100{ }^{\circ} \mathrm{C}$ for $1-1.5 \mathrm{~h}$. The filtered fat was then mixed with anhydrous $\mathrm{Na}_{2} \mathrm{SO}_{4}$, which was then centrifuged at $3000 \mathrm{rpm}$ for $20 \mathrm{~min}$. The oil layer was decanted, filtered with 
Whatman paper, which was covered with anhydrous $\mathrm{Na}_{2} \mathrm{SO}_{4}$. The solution is stored in a refrigerator at $<4{ }^{\circ} \mathrm{C}$ in an Eppendorf tube [24].

\section{Derivatization}

$200 \mu \mathrm{l}$ of oil/fat (from Sprague Dawley rats, chickens, goats, and cows) were added with $1.0 \mathrm{ml}$ of n-hexane, and $200 \mathrm{ml}$ of $\mathrm{NaOH}$ solution in methanol was heated for 10 min while shaken out. The mixture was then added with a BF3 solution of $1.5 \mathrm{ml}$ and heated for $10 \mathrm{~min}$. After that, it was added with saturated $\mathrm{NaCl}$ of $1.5 \mathrm{ml}$ and vortexed for $10 \mathrm{~min}$. Supernatants that contained fatty acid methyl ester (FAME) derivatives were taken and injected into the gas chromatograph system [24].

\section{Instrumentation system}

The separation was conducted in a research DBI-MS column, $30 \mathrm{MX}$ $0.25 \mathrm{~mm}$ ID, $0.25 \mu \mathrm{m}$; with a stationary phase of Polymethyl Ciloxan, injector temperature of $230{ }^{\circ} \mathrm{C}$, column temperature of $70^{\circ} \mathrm{C}$ (which then increased to $300{ }^{\circ} \mathrm{C}$ ) with an increase of $10^{\circ} \mathrm{C} / \mathrm{min}$ and water rate of $1.15 \mathrm{ml} / \mathrm{min}$. The mobile phase used was Helium gas. The MS detector used was a $70 \mathrm{MeV}$ Electron Multifier Detector (EMD). The result of the analysis was in the form of a mass spectrum compared to the WILLEY147 and NIST47 library-contained in the GCMS software.

\section{Data analysis}

The chromatogram data of fatty acid methyl ester content from each Sprague Dawley rats, boars, goats, and cows were grouped using chemometrics PCA with Minitab 19 [25]

\section{RESULTS AND DISCUSSION}

\section{Fat extraction}

The fat extraction was carried out using the dry rendering method, which was by using an oven at a temperature of $100{ }^{\circ} \mathrm{C}$ for $60-90$ min. That method was chosen because it can prevent the loss of volatile oil components, have a simple implementation, and cheapsince it did not use additional chemicals and yields a lot [19]. The yields are presented in table 1.

Table 1: The yield of fat extraction

\begin{tabular}{|c|c|c|c|c|c|}
\hline Type of fat & Fat weight (gram) & Oil weight (gram) & Oil color & Oil physical form (Room temperature) & Yield \% \\
\hline Sprague Dawley rats & 25.67 & 9.44 & Clear White & Liquid & 36.77 \\
\hline Boars & 50.96 & 6.99 & Clear yellow & Liquid & 13.70 \\
\hline Goats & 50.39 & 9.56 & White & Solid & 18.97 \\
\hline Cows & 50.18 & 3.27 & White & Solid & 6.52 \\
\hline
\end{tabular}

The yield percentage difference can be caused by the presence of both saturated and unsaturated triacylglycerides and nontriacylglyceride components found in each animal fat. The components of each oil can be affected by the extraction process, the animal parts/organs taken, animal species, as well as animal intake.

\section{Fat derivatization}

The extracted oil or fat cannot evaporate; therefore, the derivatization into the form of methyl ester should be done in order to become a volatile compound [23]. A volatile compound is a requirement of separating the mixture by gas chromatography. Derivatization of fatty acid can be done both through acid and base [24].

The derivatization was carried out using BF3 in methanol as an acid catalyst. BF3 was chosen because it has the advantage of being able to methylate fatty acid quickly. Also, when combined with the saponification reaction, which in this case is the addition of $\mathrm{NaOH}$ in methanol, $\mathrm{BF} 3$ can methylate fatty acid even quicker. $\mathrm{NaOH}$ was chosen because it can separate the phases properly [24].

In this research, it was added with $\mathrm{NaCl}$, which functions as a precipitate of glycerolate from the breakdown of triglycerides into fatty acid. Sodium in $\mathrm{NaCl}$ salt will bind with glycerol and become sodium glycerolate [25]. The supernatant taken is the upper phase since Fatty Acid Methyl Ester (FAME) has the lowest specific gravity compared to other phases. The middle phase is a phase that contains methanol and water mixed with glycerol, while the lower phase is sodium glycerolate sediments. This Fatty Acid Methyl Ester (FAME) phase is injected into the GC-MS system (fig. 1).

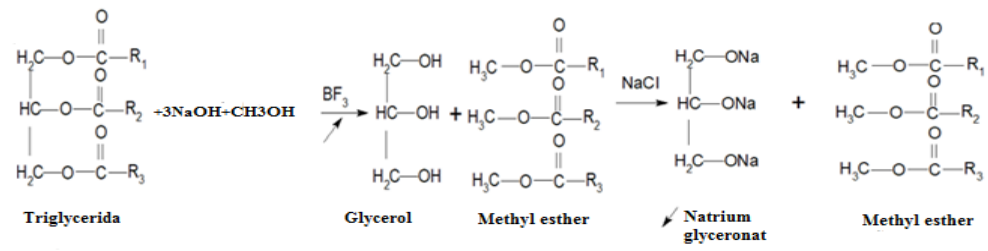

Fig. 1: FAME composing reaction

\section{Profile of the Sprague Dawley rats' fatty acid}

The analysis of the profile of Sprague Dawley rats' fatty acid was done using the methyl ester form. The parameters used are Time retention (Tr) and Similarity Index (SI); to determine the closeness of the chemical structure of fatty acid types-which were compared between standard targets and fatty acid in spectra from the WILLEY147 and NIST147 library found in the GC-MS software. If the SI result $>90$, it shows similarity to the target spectra [19]. Table II shows the Sprague Dawley rats' fatty acid in the form of methyl esters.

Table 2: Analysis of separation and identification of Sprague Dawley rat fat with GC-MS

\begin{tabular}{|c|c|c|c|c|c|c|}
\hline No & $\operatorname{Tr}(\min )$ & $\mathrm{x} \pm \mathrm{SD},(\mathrm{N}=3)$ & CV & SI & MW & Component \\
\hline 1 & 19.23 & $0.18 \pm 0.01$ & 8.18 & 95 & 242 & Methyl Miristate (14:0) \\
\hline 2 & 19.87 & $0.14 \pm 0.01$ & 7.14 & 95 & 256 & Methyl Pentadekanoate (15:0) \\
\hline 3 & 20.59 & $1.14 \pm 0.06$ & 5.80 & 95 & 268 & Methyl Palmitoleate (16:1) \\
\hline 4 & 20.85 & $19.75 \pm 0.09$ & 0.48 & 97 & 270 & Methyl Palmitate (16:0) \\
\hline 5 & 24.21 & $0.15 \pm 0.015$ & 9.96 & 95 & 284 & Methyl Margarate (17:0) \\
\hline 6 & 25.63 & $32.24 \pm 1.46$ & 4.54 & 91 & 294 & Methyl Linoleate (18:2) \\
\hline 7 & 25.90 & $43.32 \pm 1.43$ & 3.30 & 95 & 296 & Methyl Oleate (18:1) \\
\hline 8 & 26.58 & $0.26 \pm 0.01$ & 5.43 & 95 & 298 & Methyl Stearate (18:0) \\
\hline
\end{tabular}

$\operatorname{Tr}$ (Time retensi); $\mathrm{x}=\%$ area; $\mathrm{SD}$ (standard deviation); $\mathrm{N}=$ replication, $\mathrm{CV}=$ Coefficient of variation, SI (Similirity Index); MW (Molecular Weight) 
The result of the GC-MS analysis is in table 2. Oleate is the highest constituent component of fatty acid in Sprague Dawley $(S D)$ rats (43.32\%), followed by linoleate $(32.24 \%)$, palmitate $(19.75 \%)$, palmitoleate $(1.14 \%)$, stearate $(0.26 \%)$, myristate $(0.18 \%)$, margarine $(0.15 \%)$ and pentadecanoate $(0.14 \%)$. Guntarti's research [26] stated that fatty acid compounds that appear with the highest peak in 'house rats' are trans-9-octadecenoic or elaidic acid. Meanwhile, it stated that Wistar rats contain six types of methyl esters, the highest being oleate $(40.48 \%)$, followed by linoleate (30.14\%). Wistar and Sprague Dawley rats are both often used as experimental animals in research. Fig. 2 shows the comparison of the content of methyl esters in Wistar and Sprague Dawley rats.

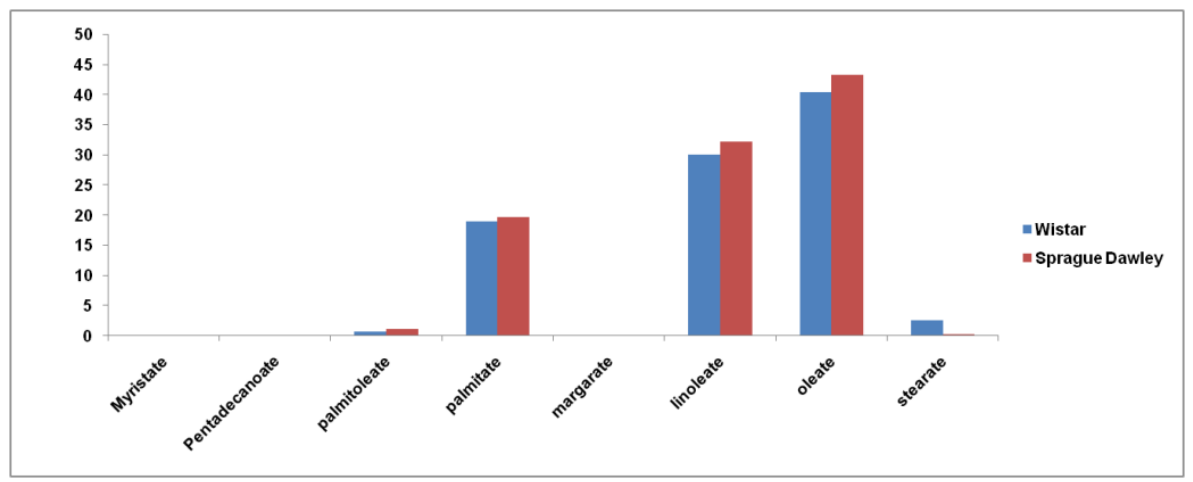

Fig. 2: Comparison of methyl ester of wistar and Sprague Dawley rat

Based on fig. 2, Wistar and Sprague Dawley rats have the same main content of fatty acids-namely palmitate, linoleate, and oleate. Palmitate is a saturated fatty acid, while linoleate and oleate are unsaturated fatty acids. Therefore, if they are summed up and totaled, the high fatty acid is an unsaturated fatty acid. The difference in fatty acid composition in each rat can be caused by the differences in species used or the influence of the animals' habitat and food.

The amount of unsaturated fatty acid content can affect the physical form in room temperature and fat stability: the higher the unsaturated fatty acid content, the lower the melting point will be [27]. It can be seen that Sprague Dawley rats have dominant unsaturated fatty acids-which means their melting point is lower. The result of the Sprague Dawley rats extraction showed that the physical form of the oil was liquid at room temperature.

\section{Comparison of Sprague Dawley rats, boars, goats, and cows fatty acid}

The process of taking fat and derivatization on boars, goats, and cows is similar to $S D$ rats. Table 3 shows the result of methyl ester's acquisition of $S D$ rats and other animals.

In table III, it can be seen that one of the characteristics of $S D$ rats' fatty acid is that; they have Linoleate fatty acid (18: 2), which other animals do not have. The result of the analysis of fat profiles in boars, goats, and cows is a shift in the fatty acid content compared to previous research [26]. Guntarti's research [20] shows that boars' fatty acid has higher unsaturated fatty acids, while cows' fatty acid has higher saturated fatty acids. The differences in fatty acid constituents can be caused by the differences in animals' origin, food, or species (fig. 3).

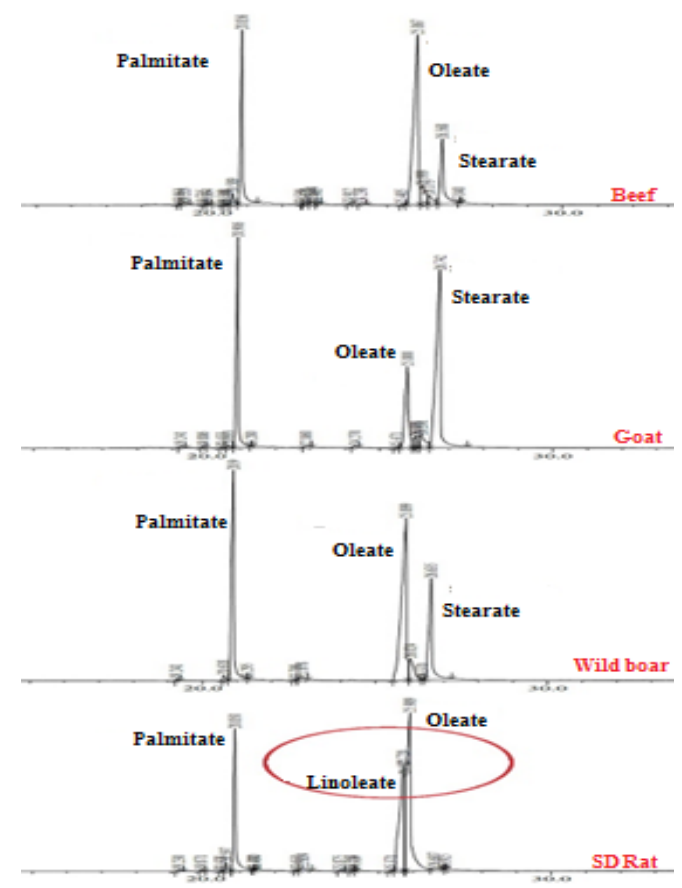

Fig. 3: Chromatogram of Sprague Dawley rat, wild boar, goat, and cow the $x$-axis was $\operatorname{Tr}$ (retention time), and the $y$-axis was total ion chromatogram (TIC)

Table 3: Percentage of methyl ester in Sprague Dawley rat fat, wild boar, goat, and cow

\begin{tabular}{|c|c|c|c|c|}
\hline \multirow{2}{*}{ Methyl ester } & \multicolumn{4}{|c|}{ Percentase (\%) methyl ester ( $\mathrm{x} \pm \mathrm{SD}), \mathrm{N}=3$} \\
\hline & Sprague Dawley rat & Wild boar & Goat & Beef \\
\hline Myristate (14:0) & $0.18 \pm 0.01$ & $0.09 \pm 0.01$ & $0.12 \pm 0.01$ & $0.22 \pm 0.03$ \\
\hline Pentadekanoate (15:0) & $0.14 \pm 0.01$ & $\mathrm{Nd}$ & $0.11 \pm 0.02$ & $0.06 \pm 0.01$ \\
\hline Palmitoleate (16:1) & $1.14 \pm 0.06$ & $0.72 \pm 0.01$ & $0.37 \pm 0.04$ & $1.66 \pm 0.12$ \\
\hline Palmitate $(16: 0)$ & $19.75 \pm 0.09$ & $29.01 \pm 0.77$ & $27.65 \pm 0.29$ & $24.16 \pm 0.36$ \\
\hline Margarate $(17: 0)$ & $0.15 \pm 0.015$ & $\mathrm{Nd}$ & $0.29 \pm 0.02$ & $0.30 \pm 0.02$ \\
\hline Linoleate (18:2) & $32.24 \pm 1.46$ & $\mathrm{Nd}$ & $\mathrm{Nd}$ & $\mathrm{Nd}$ \\
\hline Oleate $(18: 1)$ & $43.32 \pm 1.43$ & $43.70 \pm 0.28$ & $3.99 \pm 0.20$ & $50.05 \pm 0.67$ \\
\hline Stearate $(18: 0)$ & $0.26 \pm 0.01$ & $19.88 \pm 1.40$ & $45.38 \pm 1.19$ & $13.97 \pm 0.01$ \\
\hline
\end{tabular}

*Nd: Not detected, $\mathrm{SD}=$ standard of deviation, $\mathrm{N}=$ Replication 
Fig. 3 shows that chromatogram peak linoleate only appears in Sprague Dawley rats. The $\mathrm{x}$-axis on the chromatogram in fig. 3 is time retention, while the $y$-axis is TIC (Total Ion Chromatogram). TIC is a chromatogram that is made by summing up the intensity of all mass spectral peaks, which are included in the same scan [28]. When observed from the number of fatty acid constituents, it can be seen that $S D$ rats have the most unsaturated fatty acid among the other animals (fig. 4).

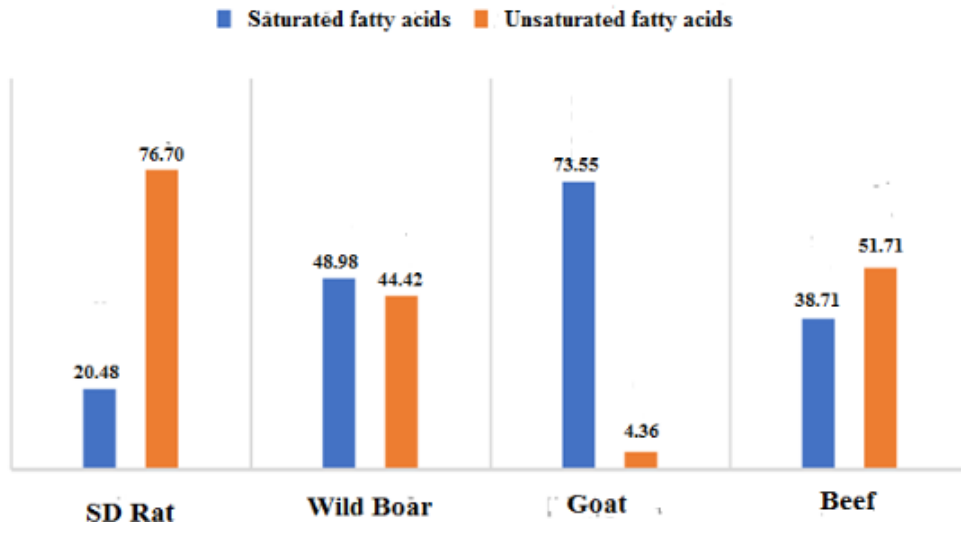

Fig. 4: Fatty acids in Sprague Dawley rat, wild boar, goat, and cow

Based on fig. 4, the highest constituent of Sprague Dawley rats' total fatty acid is $97.18 \%$; boars $93.4 \%$; goats $77.91 \%$, and cows $90.42 \%$. Most likely, this difference occurs from the extraction process, the process of separation in GC, food intake, as well as the animal parts/organs taken.

Principal component analysis (PCA) of methyl ester fatty acid in Sprague Dawley rats, boars, goats, cows, as well as meatball sample products

Principal Component Analysis (PCA) data interpretation is made by reducing data, where the number of variables in a matrix is reduced to produce new variables while maintaining the information owned by the data [29]. The sample was chosen: meatball. Meatball is one of the processed foods derived from animals, which is much in demand by society. The common trend of mixing meatball with rat meat has made people uneasy. The result of the analysis of methyl esters in processed food samples (meatball) is listed in table 4.
Table IV shows that the three samples of meatball have the same type of fatty acid profile, which consists of 7 types of fatty acidswhere five are saturated fatty acids, and 2 are unsaturated fatty acids. Although the types of fatty acid which appear are similar; the amount of each fatty acid has a different value. The difference between the fat of Sprague Dawley rats and meatball (samples A, B, and $C$ ) is in the linoleate fatty acid. In the previous explanation with boars, goats, and cows, the difference is also in linoleate fatty acid content. This shows that linoleic acid is the typical fatty acid in rats, which are often used as research trials, namely Wistar and Sprague Dawley rats.

The PCA analysis variable is a type of fatty acid. The type of matrix chosen was the correlation that connected the types of a sample with fatty acid. The information obtained from PCA analysis showed the similarity between the fatty acid in Sprague Dawley rats, boars, goats, cows, as well as meatballs (samples A, B, and C).

Table 4: The result of the acquisition of methyl ester percentage in the fat of Sprague Dawley rats' and meatballs (Sample A, B, and C)

\begin{tabular}{|c|c|c|c|c|}
\hline \multirow[t]{2}{*}{ Methyl esther } & \multicolumn{4}{|c|}{ Methyl ester (Percentage ((x \pm SD)\%, $N=3$} \\
\hline & Sprague Dawley rats & Meatball (sample A) & Meatball (sample B) & Meatball (sample C) \\
\hline Myristate (14:0) & $0.18 \pm 0.01$ & $0.46 \pm 0.03$ & $0.52 \pm 0.07$ & $1.13 \pm 0.12$ \\
\hline Pentadekanoate (15:0) & $0.14 \pm 0.01$ & $0.19 \pm 0.01$ & $0.20 \pm 0.02$ & $0.10 \pm 0.007$ \\
\hline Palmitoleate (16:1) & $1.14 \pm 0.06$ & $1.82 \pm 0.10$ & $1.08 \pm 0.19$ & $0.98 \pm 0.14$ \\
\hline Palmitate (16:0) & $19.75 \pm 0.09$ & $28.12 \pm 0.04$ & $26.51 \pm 2.07$ & $35.07 \pm 0.23$ \\
\hline Margarate $(17: 0)$ & $0.15 \pm 0.015$ & $0.45 \pm 0.02$ & $0.65 \pm 0.01$ & $0.31 \pm 0.02$ \\
\hline Linoleate (18:2) & $32.24 \pm 1.46$ & $\mathrm{Nd}$ & $\mathrm{Nd}$ & $\mathrm{Nd}$ \\
\hline Oleate (18:1) & $43.32 \pm 1.43$ & $32.3 \pm 0.53$ & $31.35 \pm 2.09$ & $23.58 \pm 0.41$ \\
\hline Stearate (18:0) & $0.26 \pm 0.01$ & $17.72 \pm 0.18$ & $27.28 \pm 0.60$ & $27.92 \pm 1.59$ \\
\hline
\end{tabular}

*Nd: Not detected, $\mathrm{SD}=$ standard Deviation, $\mathrm{N}=$ Replication

Table 5. The report of PCA analysis of Sprague Dawley Rat, other animal and sample product at markets of its eigen analysis

\begin{tabular}{|c|c|c|c|c|c|c|c|c|}
\hline \multicolumn{9}{|c|}{ Eigen analysis of the correlation matrix } \\
\hline Eigenvalue & 3.4722 & 2.1684 & 1.3563 & 0.7367 & 0.1907 & 0.0598 & 0.014 & 0.0016 \\
\hline Proportion & 0.434 & 0.271 & 0.170 & 0.092 & 0.024 & 0.007 & 0.002 & 0.000 \\
\hline Comulative & 0.434 & 0.705 & 0.875 & 0.967 & 0.991 & 0.998 & 1.000 & 1.000 \\
\hline Variable & PC1 & PC2 & PC3 & PC4 & PC5 & PC6 & PC7 & PC8 \\
\hline Myristate & 0.297 & 0.297 & 0.366 & -0.642 & $-0,205$ & -0.365 & 0.321 & -0.014 \\
\hline Pentadecanoate & 0.070 & 0.572 & -0.424 & -0.098 & 0.141 & 0.519 & 0.383 & 0.205 \\
\hline Palmitoleate & -0.189 & 0.502 & 0.386 & 0.266 & 0.608 & -0.289 & -0.132 & 0.150 \\
\hline Palmitate & 0.448 & -0.085 & 0.408 & -0.213 & 0.185 & 0.567 & -0.458 & $0.12-0.197$ \\
\hline Margarate & 0.266 & 0.535 & -0.167 & 0.253 & -0.486 & -0.127 & -0.510 & 0.352 \\
\hline Linoleate & -0.419 & 0.039 & -0.330 & -0.565 & 0.042 & -0.133 & -0.502 & 0.465 \\
\hline Oleate & -0.426 & 0.094 & 0.446 & 0.169 & -0.544 & 0.247 & 0.092 & 0.736 \\
\hline stearate & 0.493 & -0.473 & -0.188 & 0.266 & -0.004 & -0.312 & 0.046 & \\
\hline
\end{tabular}


The PCA analysis conducted using minitab19 software had obtained 8 PCs. The selection of the number of PCs in PCA can be determined by observing the eigenvalue obtained from the PCA result. The number of PCs relevant to explaining the preliminary information from data is a PC with an eigenvalue $>1$. Below this limit, PCs are considered irrelevant. Table 5 shows that the PCA analysis produced 8 PCs. PC1, with an eigenvalue of 3.4722 , can describe $43.4 \%$ of the total original data variable. PC2, with an eigenvalue of 2.1684 , can describe $27.1 \%$ of the total original variable. PC3, with an eigenvalue of 1.3563 , is able to describe $17.0 \%$ of the total original variables. Therefore, only by using 3PCs; can one already describe $87.5 \%$ of all original data variables and is relevant enough to explain the characteristics of the initial variables [29]. Fig. 5 shows the result of the fatty acid plot score: Sprague Dawley rats, boars, goats, cows, as well as meatball (sample A, B and C).

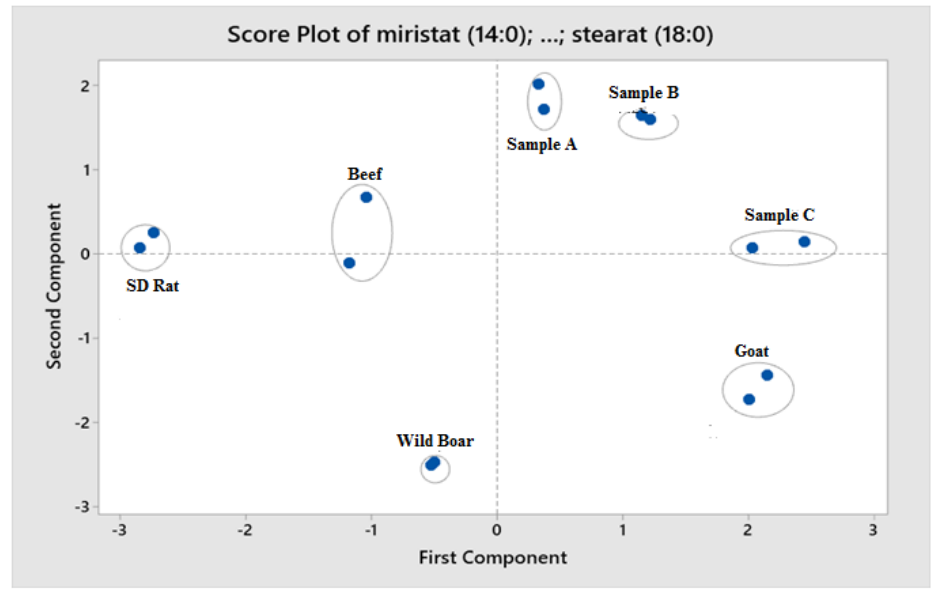

Fig. 5: Score plot of PCA analysis of SD rat, wild boar, goat, cow, and meatballs sample market: A, B, and C

Fig. 5 shows that PCA chemometrics is able to classify the fat of Sprague Dawley rats, boars, goats, cows, as well as meatballs (samples A, B, and C). The meatball samples' scores are very distant from the Sprague Dawley rats. Therefore, it can be concluded from the Plot Score that meatball (samples A, B, and C) do not have Sprague Dawley rats' fat content. The very distant score between Sprague Dawley rats with other animals and meatball (samples A, B, and C) is because linoleate fatty acid is only owned by Sprague Dawley rats-which means it cannot be found in the meatball samples.

\section{CONCLUSION}

The constituents of Sprague Dawley rats' (Rattus norvegius) fat analyzed by gas chromatography-mass spectrometry (GC-MS) method consist of 8 types of fatty acid; namely oleate (43.32\%), linoleate $(32.24 \%)$, palmitate $(19.75 \%)$, palmitoleate $(1.14 \%)$, stearate $(0.26 \%)$, myristate $(0.18 \%)$, margarate $(0.15 \%)$ and pentadecanoate $(0.14 \%)$. The GC-MS method combined with PCA (Principal Component Analysis) chemometric is able to classify the fat of Sprague Dawley rats' (Rattus norvegius), with other animals and samples of processed meatballs on the market.

\section{THANK-YOU NOTE}

Thank you to LPPM Ahmad Dahlan of University for facilitating this research until it is finished.

\section{FUNDING}

Nil

\section{AUTHORS CONTRIBUTIONS}

All the authors have contributed equally.

\section{CONFLICT OF INTERESTS}

Declared none

\section{REFERENCES}

1. Aparicio R, Morales MT, Aparicio Ruiz R, Tena N, Garcia Gonzalez DL. Authenticity of olive oil: mapping and comparing official methods and promising alternatives. Food Res Int 2013;54:2025-38.

2. Fajardo V, Gonzalez Isabel I, Rojas M, Garcia T, Martin R. A review of current PCR-based methodologies for the authentication of meats from game animal species. Trends Food Sci Technol 2010;21:408-21.

3. Che Man YB, Rohman A, Mansor TST. Differentiation of lard from other edible fats and oils by means of Fourier transform infrared spectroscopy and chemometrics. JAOCS, J Am Oil Chem Soc 2011;88:187-92.

4. Lusas EW. Animal and Vegetable Fats, Oils, and Waxes Biotechnology. In: Agriculture and processing human survival is biotechnology; 2015. p. 243-328.

5. Danezis GP, Tsagkaris AS, Camin F, Brusic V, Georgiou CA. Food authentication: techniques, trends and emerging approaches. TrAC-Trends Anal Chem 2016;85:123-32.

6. Pinto A Di, Pinto P Di, Terio V, Bozzo G, Bonerba E, Ceci E. Short communication DNA barcoding for detecting market substitution in salted cod fillets and battered cod chunks. Food Chem 2013;141:1757-62.

7. Von Bargen C, Dojahn J, Waidelich D, Humpf HU, Brockmeyer J. New sensitive high-performance liquid chromatographytandem mass spectrometry method for the detection of horse and pork in halal beef. J Agric Food Chem 2013;61:11986-94.

8. Kurniasih KSI, Hikmah N, Erwanto Y, Rohman A. Qualitative and quantitative analysis of canine (canis lupus familiaris) meat in meatballs for halal authentication study using real-time polymerase chain reaction. Int J Agric Biol 2020;23:103-8.

9. Tarola AM, Girelli AM, Lorusso S. High performance liquid chromatography determination of fatty acids in drying oils following lipase action. J Chromatogr Sci 2012;50:294-300.

10. Figueiredo IL, Claus T, Oliveira Santos Junior O, Almeida VC, Magon T, Visentainer JV. Fast derivatization of fatty acids in different meat samples for gas chromatography analysis. J Chromatogr A 2016;1456:235-41.

11. Rahayu WS, Martono S, Sudjadi, Rohman A. The potential use of infrared spectroscopy and multivariate analysis for differentiation of beef meatball from dog meat for Halal authentication analysis. J Adv Vet Anim Res 2018;5:307-14.

12. Yuliani F, Riyanto S, Rohman A. Application of ftir spectra combined with chemometrics for analysis of candlenut oil adulteration. Int J Appl Pharm 2018;10:54-9.

13. Nurjuliana M, Che Man YB, Mat Hashim D. Analysis of lard's aroma by an electronic nose for rapid Halal authentication. JAOCS, J Am Oil Chem Soc 2011;88:75-82.

14. Salamah N, Erwanto Y, Martono S, Maulana I, Rohman A. Differentiation of bovine and porcine gelatines using lc-ms $/ \mathrm{ms}$ and chemometrics. Int J Appl Pharm 2019;11:159-63. 
15. Windarsih A, Rohman A, Swasono RT. Authentication of turmeric using proton-nuclear magnetic resonance spectroscopy and multivariate analysis. Int J Appl Pharm 2018;10:174-80.

16. Indrasti D, Che Man YB, Mustafa S, Hashim DM. Lard detection based on fatty acids profile using comprehensive gas chromatography hyphenated with time-of-flight mass spectrometry. Food Chem 2010;122:1273-7.

17. Hausman GJ, Bergen WG, Etherton TD, Smith SB. The history of adipocyte and adipose tissue research in meat animals. J Anim Sci 2018;96:473-86.

18. Erwanto Y, Abidin MZ, Muslim EYP, Sugiyono S, Rohman A. Identification of pork contamination in meatballs of Indonesia local market using polymerase chain reaction-restriction fragment length polymorphism (PCR-RFLP) analysis. AsianAustralasian J Anim Sci 2014;27:1487-92.

19. Guntarti A, Prativi SR. Application method of fourier transform infrared (FTIR) combined with chemometrics for analysis of rat meat (Rattus Diardi) in meatballs beef. Pharmaciana 2017;7:133.

20. Guntarti A. Authentication of dog fat with gas chromatographymass spectroscopy combined with chemometrics. Int J Chem 2018:10:124

21. Rahmania H, Rohman A. The employment of FTIR spectroscopy in combination with chemometrics for analysis of rat meat in meatball formulation. MESC 2015;100:301-5.

22. Lumakso FA, Riyanto S, Ahmad S, Ahmad S, Salleh A, Mohd F, et al. Application of chemometrics in combination with fourier transform mid infrared spectroscopy for authentication of avocado oil. J Food Pharm Sci 2015;3:12-7.

23. Rohman A, Himawati A, Triyana K, Sismindari, Fatimah S. Identification of pork in beef meatballs using fourier transform infrared spectrophotometry and real-time polymerase chain reaction. Int J Food Prop 2017;20:654-61.

24. Rohman A, Triyana K, Sismindari, Erwanto Y. Differentiation of lard and other animal fats based on triacylglycerols composition and principal component analysis. Int Food Res J 2012;19:475-9.

25. Rahayu WS, Rohman A, Sudjadi, Martono S. Identification of dog for halal autentification with gas chromatography mass spectroscopy (GCMS) and chemometrics. Adv Sci Lett 2018;24:138-41.

26. Guntarti A, Gandjar IG, Jannah NM. Authentication of wistar rat fats with gas chromatography mass spectometry combined by chemometrics. Potravin Slovak J Food Sci 2020;14:52-7.

27. Indriyani L, Rohman A, Riyanto S. Authentication of avocado oil (Persea americana Mill.) using differential scanning calorimetry and multivariate regression. Asian J Agric Res 2016;10:78-86.

28. Johnsen LG, Skou PB, Khakimov B, Bro R. Gas chromatographymass spectrometry data processing made easy. J Chromatogr A 2017; 1503:57-64.

29. Miller J, Miller J. Statistics and chemometrics for analytical chemistry. Sixth edition. Vol. 6th Pearson Education Limited 2010 . 